\title{
Recollections of a Judge
}

\author{
Sabino Cassese
}

\begin{abstract}
As a former justice of the Italian Constitutional Court serving at the time of Sentenza 238/2014, this chapter illustrates my major concerns towards this Judgement. I outline several reasons for a possible 'dissent' (procedural, factual, constitutional, theoretical and strategic). With ex post remarks, the chapter elaborates some additional thoughts on the unnecessary opposition between national and international law and on certain Italian ambiguities towards its past.
\end{abstract}

\section{Introduction}

As I am the only author in this volume who can provide a view from the inside, I shall speak as a witness and not as a scholar, making ex-post public my dissent as a former justice of the Corte Costituzionale (ItCC) who decided Sentenza 238/2014 in October 2014.

In my dissent I was not alone. A large minority of the ItCC was opposed to the Judgment, and in my nine years at the ItCC, this was the most divisive of all its judgments. ${ }^{1}$ In fact, I was very close to resigning from the Court. For procedural reasons, if I had resigned, the judgment would not have been adopted. As it happened, however, I was convinced by those minority members who were against Sentenza that it would have been better not to resign. Nevertheless, I did not participate in the meeting in which the decision was read.

My dissent was based on five points: procedural, factual, constitutional, theoretical, and strategic, to which now, a few years later, I can add a few comments.

\footnotetext{
${ }^{1}$ Sabino Cassese, Dentro la Corte: Diario di un giudice costituzionale (Bologna: Il Mulino 2015).

S. Cassese $(\bowtie)$

LUISS Guido Carli University, School of Government, Rome, Italy

e-mail: sabino@sabinocassese.eu 


\section{Reasons for Dissent}

\section{Procedural}

As it is well known, constitutional courts engage themselves in either abstract or concrete review. The French Conseil Constitutionnel, until the question prioritaire de constitutionnalite,${ }^{2}$ had only abstract review powers. In our case, the ItCC has the power of concrete review. Concrete review means that the case has been raised in a case or controversy, to use the American legal terminology. However, the case must be ripe; and citing William Shakespeare, 'ripeness is all'. 3

The first problem for the ItCC was indeed to decide if this case was ripe or not. The Tribunale di Firenze, the court that raised the case, was in that phase of the procedure we call giudizio di cognizione and not in a giudizio di esecuzione, and did not really demonstrate whether the case before it was indeed ripe. ${ }^{4}$ Therefore, in my opinion, the correct decision for the court would have been to judge the case inadmissible without even entering into the merits of the question.

\section{Factual}

The second point is more complex. Germany had paid in the past a large amount of money to the Italian government, ${ }^{5}$ which was not given directly to the victims but instead used to rebuild those parts of the country that had been partly destroyed during the war. ${ }^{6}$ In other words, the money was directed to national purposes other than for those victims directly affected by Nazis crimes. It was not the German government but the Italian one to choose who would have been the beneficiaries of those funds.

\footnotetext{
${ }^{2}$ French Constitutional Law 23 July 2008, No 2008-724.

${ }^{3}$ William Shakespeare, King Lear, Act V, Scene II, Reginald A Foakes (ed) (London: The Arden Shakespeare new ed 1997) 363.

${ }^{4}$ Tribunale di Firenze, Orders of 21 January 2014, Nos 84/2014, 85/2014, 113/2014.

${ }^{5} \mathrm{Cf}$ Agreement between the Federal Republic of Germany and Italy on the Compensation for Italian Nationals Subjected to National-Socialist Measures of Persecution (Bonn, 2 June 1961), German and Italian version published in Bundesgesetzblatt II 5 July 1963 No 22, 791.

${ }^{6} \mathrm{Cf}$ ICJ, Jurisdictional Immunities of the State (Germany v Italy: Greece intervening), Judgment of 3 February 2012, ICJ Reports 2012, 99, para 101.
} 


\section{Constitutional}

Article 24 of the Italian Constitution provides the right to a judge. Is this a right to an Italian judge or is this a right to any judge? This question was particularly relevant for Sentenza 238/2014 because several cases had been raised before lower courts in Germany and once even before the German Federal Constitutional Court (FCC). ${ }^{7}$ If one person has a right to a judge and had the opportunity to bring their case before a judge in Germany, why raise the same case in Italy while complaining that in fact they did not have an opportunity to have their case reviewed by a judge? ${ }^{8}$

\section{Theoretical}

Why set domestic law against international law, and in the process declare international law unconstitutional (a point later raised by Stefano Battini in an excellent commentary to Sentenza 238/2014) ${ }^{9}$ ? With that Judgement, the ItCC has revived Heinrich Triepel and the dualism national-international. The Court could have taken another route: not to oppose the national to the international plan but to recognize that international law also has a well-established principle that safeguards access to justice. Therefore, the ItCC had the opportunity to oppose state immunity from jurisdiction to another international law principle.

\section{Strategic}

This Judgement was also an example of legal protectionism. To build walls around a national legal order is not a good strategy for a constitutional court; it is better to open the doors to supranational and universal principles. ${ }^{10}$ This was a contradictory behaviour in the strategy of the ItCC. We would do well to remember that the ItCC in 2007 opened its doors to the Strasbourg court and to the European Convention on

\footnotetext{
${ }^{7}$ Bundesverfassungsgericht, Order of 28 June 2004, 2 BvR 1379/01, BVerfGK 3, 277; Eg Verwaltungsgericht Berlin, Judgment of 9 September 2004, 9 A 336.02.

${ }^{8} \mathrm{Cf}$ Valerio Onida, chapter 'Moving Beyond Judicial Conflict in the Name of the Pre-Eminence of Fundamental Human Rights', in this volume.

${ }^{9}$ Stefano Battini, 'È costituzionale il diritto internazionale?', Giornale di diritto amministrativo 3 (2015), 367-377, at 372-373.

${ }^{10}$ See also Sabino Cassese, I tribunali di Babele: I giudici alla ricerca di un nuovo ordine globale (Rome: Donzelli editore 2009).
} 
Human Rights, ${ }^{11}$ and later to the law of the European Union. ${ }^{12}$ That Court had established a dialogue. Therefore, the strategy of the ItCC was inconsistent. Constitutional courts should not go in search of national 'identities', like the FCC, ${ }^{13}$ because we all have plural identities. For the same reason, courts should not oppose their national constitutions to international law.

\section{Ex Post Remarks}

Ex post, there are three additional comments I would like to make. Firstly, the majority of the Court's justices fell prey to the worst temptation for a constitutional judge: to write 'the great judgment'. You may know pages by Guido Calabresi ${ }^{14}$ against judges wanting to put their name under an important judgment. Secondly, the majority followed one epistemic community, that of international lawyers. This was another contradiction because international lawyers have put themselves against international law. Thirdly, no constitutional judge should try to write history in the courtroom: ${ }^{15}$ judges are judges, historians are historians.

That being said, let me put my opinion in a more constructive manner. I thought that the ItCC could have taken the following decision: 'Tribunal of Florence: you are raising the right question in the wrong manner. It is true that there is problem of access to justice, but you are interpreting Article 24 of the Italian Constitution in a very strict manner. There are hundreds of decisions by the Italian Council of State that establish that Article 24 covers also what we call deliberative democracy, that is taking decisions by administrative bodies after consultation and discussion with the people affected or who are going to be affected by the decisions. Therefore, I accept your point, but I conclude that there is an obligation of the two governments to consult and reach an agreement between themselves and with the affected people'.

If we recall the famous Canadian Supreme Court decision on the secession of Quebec, ${ }^{16}$ we will remember that it was simple: Quebec had right to secede, but could not exercise this right unilaterally without entering into negotiations with the rest of Canada.

A few years ago, I was at the Global Constitutionalism Seminar at Yale University, and one theme was state immunity in comparative terms. The conclusion was

\footnotetext{
${ }^{11}$ Corte Costituzionale, Judgments of 22 October 2007, Nos 348 and 349/2007.

${ }^{12} \mathrm{Cf}$ Corte Costituzionale, Order of 13 February 2008, No 103/2008; Corte Costituzionale Order of 3 July 2013, No 207/2013.

${ }^{13}$ Bundesverfassungsgericht, Decision of 15 December 2015, 2 BvR 2735/14, BVerfGE 140, 317 (European Arrest Warrant II/Identity Control).

${ }^{14}$ Guido Calabresi, Il mestiere di giudice: Pensieri di un accademico americano (Bologna: Il Mulino 2014).

${ }^{15}$ See also Andreas von Arnauld, chapter 'Deadlocked in Dualism', in this volume.

${ }^{16}$ Supreme Court of Canada, Reference Re Secession of Quebec, [1998] 2 SCR 217.
} 
that immunities are being eroded. They are similar to shared sovereignty, an oxymoron, because if states are sovereign, they cannot share sovereignty. If they share it, they are no longer sovereign. The same is true for immunity, which has been eroded in different ways by the international community. ${ }^{17}$

\section{Italian Ambiguities Towards Fascism}

I would like to make a final point on the Italian ambiguities towards Fascism. Ambiguities that are evidenced by different viewpoints on national history. Was the nature of Italian Fascism one of authoritarianism, totalitarianism (according to the Hannah Arendt definition), ${ }^{18}$ or was it in reality a dictatorship?

Renzo De Felice, Italy's preeminent historian of Mussolini and Fascism, did not entirely share the idea that it was a totalitarian state, while his pupil, Emilio Gentile, on the other hand, is in favour of defining Italy's Fascist regime as totalitarian. Historians are divided on this major point. I would like to recall how De Felice's considerable biography of Mussolini was received by the public and the critics. The subtitle of that book was 'Gli anni del consenso', ${ }^{19}$ which implied that in the central years of the 'Regime' there existed a large majority of Italians in favour of Mussolini. The publication of that book raised strong reactions. When Claudio Pavone's 'Una guerra civile ${ }^{, 20}$ was published, which put forward the idea that there had been a civil war amongst Italians, it too was received with astonishment. Furthermore, the book 'La morte della Patria', ${ }^{21}$ equally deals with very divisive aspects of national history, focusing on the problem of Italians moving from being allied with the Germans to being against the Germans and therefore being divided.

All these debates highlight the difficulty of closing the 'memory book' in Italy and put Sentenza 238/2014 into a broader historical perspective which needs to be taken into consideration when discussing possible 'ways out' to the current legal deadlock.

\footnotetext{
${ }^{17}$ See also, Anne Peters/Evelyne Lagrange/Stefan Oeter/Christian Tomuschat (eds), Immunities in the Age of Global Constitutionalism (Leiden: Brill Nijhoff 2015).

${ }^{18}$ Hannah Arendt, The Origins of Totalitarianism (London: Penguin Books new ed 2017).

${ }^{19}$ Renzo De Felice, Mussolini il duce: Gli anni del consenso 1929-1936 (Turin: Einaudi 2007).

${ }^{20}$ Claudio Pavone, Una guerra civile: Saggio storico sulla moralità nella Resistenza (Turin: Bollati Boringhieri 2006).

${ }^{21}$ Ernesto Galli Della Loggia, La morte della patria: La crisi dell'idea di nazione tra Resistenza, antifascismo e Repubblica (Rome/Bari: Editori Laterza 2003).
} 


\section{References}

Arendt, Hannah, The Origins of Totalitarianism (London: Penguin Books new ed 2017)

Battini, Stefano, 'È costituzionale il diritto internazionale?', Giornale di diritto amministrativo 3 (2015), 367-377

Calabresi, Guido, Il mestiere di giudice: Pensieri di un accademico americano (Bologna: Il Mulino 2014)

Cassese, Sabino, Dentro la Corte: Diario di un giudice costituzionale (Bologna: Il Mulino 2015)

Cassese, Sabino, I tribunali di Babele: I giudici alla ricerca di un nuovo ordine globale (Rome: Donzelli editore 2009)

De Felice, Renzo, Mussolini il duce: Gli anni del consenso 1929-1936 (Turin: Einaudi 2007)

Galli Della Loggia, Ernesto, La morte della patria: La crisi dell'idea di nazione tra Resistenza, antifascismo e Repubblica (Rome/Bari: Editori Laterza 2003)

Pavone, Claudio, Una guerra civile: Saggio storico sulla moralità nella Resistenza (Turin: Bollati Boringhieri 2006)

Peters, Anne /Evelyne Lagrange/Stefan Oeter/Christian Tomuschat (eds), Immunities in the Age of Global Constitutionalism (Leiden: Brill Nijhoff 2015)

Shakespeare, William, King Lear, Act V, Reginald A Foakes (ed) (London: The Arden Shakespeare new ed 1997)

Open Access This chapter is licensed under the terms of the Creative Commons Attribution 4.0 International License (http://creativecommons.org/licenses/by/4.0/), which permits use, sharing, adaptation, distribution and reproduction in any medium or format, as long as you give appropriate credit to the original author(s) and the source, provide a link to the Creative Commons license and indicate if changes were made.

The images or other third party material in this chapter are included in the chapter's Creative Commons license, unless indicated otherwise in a credit line to the material. If material is not included in the chapter's Creative Commons license and your intended use is not permitted by statutory regulation or exceeds the permitted use, you will need to obtain permission directly from the copyright holder.

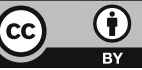

